\title{
Correction to: Analysis of local habitat selection and large-scale attraction/ avoidance based on animal tracking data: is there a single best method?
}

\author{
Moritz Mercker ${ }^{1,2^{*}}$, Philipp Schwemmer ${ }^{3}$, Verena Peschko ${ }^{3}$, Leonie Enners ${ }^{3}$ and Stefan Garthe ${ }^{3}$
}

Correction to: Mov Ecol 9, 20 (2021)

https://doi.org/10.1186/s40462-021-00260-y

Following publication of the original article [1], the authors identified an error in the affiliation list, due to a typesetting mistake: affiliations 2 and 3 were interchanged.

In addition, the authors identified an error in the captions for Tables 3 and 5 and in the first paragraph of the 'Interplay between method and tracking-data properties' section, due to a typesetting mistake. The text "above the double line" and "below the double line" should have been corrected to "above" and "below".

The affiliation list has been updated above and the original article [1] has been corrected. The original article [1] has also been corrected with regards to the errors in the captions for Tables 3 and 5 and in the first paragraph of the 'Interplay between method and tracking-data properties' section. The publisher apologises to the authors and readers for the inconvenience caused by these typesetting mistakes.

\section{Author details}

${ }^{1}$ Bionum GmbH - Consultants in Biostatistics, Hamburg, Finkenwerder Norderdeich 15 A, Hamburg, Germany. ${ }^{2}$ Institute of Applied Mathematics (IAM) Heidelberg University, Im Neuenheimer Feld 205, 69120 Heidelberg, Germany. ${ }^{3}$ Research and Technology Centre (FTZ) Kiel University, Hafentörn 1, 25761 Büsum, Germany.
Published online: 11 June 2021

\section{Reference}

1. Mercker $\mathrm{M}$, et al. Analysis of local habitat selection and large-scale attraction/avoidance based on animal tracking data: is there a single best method? Mov Ecol. 2021;9:20 https://doi.org/10.1186/s40462-021-00260-y.

*Correspondence: mmercker@bionum.de

'Bionum GmbH - Consultants in Biostatistics, Hamburg, Finkenwerder

Norderdeich 15 A, Hamburg, Germany

${ }^{2}$ Institute of Applied Mathematics (IAM) Heidelberg University, Im

Neuenheimer Feld 205, 69120 Heidelberg, Germany

C C The Author(s). 2021 Open Access This article is licensed under a Creative Commons Attribution 4.0 International License, which permits use, sharing, adaptation, distribution and reproduction in any medium or format, as long as you give appropriate credit to the original author(s) and the source, provide a link to the Creative Commons licence, and indicate if changes were made. The images or other third party material in this article are included in the article's Creative Commons licence, unless indicated otherwise in a credit line to the material. If material is not included in the article's Creative Commons licence and your intended use is not permitted by statutory regulation or exceeds the permitted use, you will need to obtain permission directly from the copyright holder. To view a copy of this licence, visit http://creativecommons.org/licenses/by/4.0/ The Creative Commons Public Domain Dedication waiver (http://creativecommons.org/publicdomain/zero/1.0/) applies to the data made available in this article, unless otherwise stated in a credit line to the data. 